\title{
Assessment and Supply Path Analysis of Hainan "No Scenic Spot ”Tourism Resources
}

\author{
Yan Jing $^{\text {a, }}{ }^{*}$, Zhu Qinfu ${ }^{b}$ \\ University of Sanya, Xueyuan Road, Sanya, China \\ a359235440@qq.com, b1803188108@qq.com \\ *corresponding author
}

Keywords: “no scenic spot” tourism resources, Tourism resources evaluation, Supply path.

\begin{abstract}
At present, the key to the development of tourism industry is to change the irrational supply structure, solve the problem of the supply and demand. Tourism resources as the basis for the development of tourism industry, the supply condition of its direct impact on tourism development and consumption patterns. Hainan tourism resources supply structure is still in scenic spot tourism resources as the main supply, can't meet the demand of tourists from sightseeing to the experience of tourism, harder to achieve pull function on the travel demand. In this paper, based on classify and evaluate of Hainan no scenic spot tourism resources, from supply mode and supply structure put forward the reform path In order to achieve the goal that from traditional tourism resources supply to "no scenic spot" tourism resources supply, such as "Provide policy support, improve the information transmission, manage the supply, to realize resource integration, pay attention to supply quality, eliminate excess supply” etc.
\end{abstract}

\section{Introduction}

The development of tourism and the gradual maturity of tourists' consumption concepts make the tourism consumption pattern change constantly, from traditional scenic spots to leisure experiences. As the basis of tourism industry development, the supply of tourism resources has a direct impact on tourism development and consumption patterns. At present, the supply structure of Hainan's tourism resources is still dominated by scenic spots tourism resources, which has not adapted to the market change and cannot meet the new demands of tourists, making it more difficult to realize the pull of tourism demand. The supply-side reform, make the tourism resources break through " scenic spots" limit, improve the utilization rate of tourism resources, solve the problem of supply vacancy and supply-demand dislocation of tourism resources, expanding the development space and promoting the upgrading of the tourism industry.

\section{Definition}

Traditionally, tourism resources have been defined as "natural, cultural objects or other factors that attract tourists and may be used to carry out tourism activities" ${ }^{[1]}$. As the tourists with outstanding personality do not accept the traditional way of sightseeing tourism, creative tourism begins to appear ${ }^{[2]}$, the concept of tourism resources as a factor of tourism market supply has also expanded from the traditional first generation "2L" tourism resources to the second generation "3S" tourism resources, then to the third generation "4Q" tourism resources ${ }^{[3]}$, and the boundary of tourism resources has entered a new stage.

There is no definition and classification of the "no scenic spot" tourism resources at present. Lv Junfang (2014) mentioned the use of "redundant" tourism resources to develop no scenic spot tourism ${ }^{[4]}$. The concept of "redundant" tourism resources was first put forward by Jin Yingruo (2004), a term used to describe the tourism resources which have high resource quality but appear "redundant" and "useless" in operation ${ }^{[5]}$. The writer thinks that: "redundant" tourism resources can be used as "no scenic spot" tourism resources, but there are differences between "no scenic spot" 
tourism resources and "redundant" tourism resources. The difference is that no scenic spot tourism resources are not necessarily "not directly functioning", but exist and play a role in other forms, such as: town, village and orchards are not special tourism resources, but can be used as tourism resources to attract tourists, developing characteristic rural tourism; Public beaches, characteristic streets and folk customs can all be used as tourist resources to attract tourists, but "tourism" is not the only value of its existence. Therefore, the writer defines "no scenic spot "tourism resources as "all resources and industrial forms which are different from direct and special scenic spot tourism resources , could attract tourists and can be used in no scenic spot tourism which increase tourists' sense of experience".

\section{Classification and evaluation of "no scenic spot" tourism resources in Hainan}

\subsection{Hainan "no scenic spot" tourism resources classification and statistics}

By using the methods of literature study, field investigation, brainstorming and expert interview, and referring to the various classification methods of tourist resources, combining with the connotation and characteristics of no scenic spot tourism, the concept of "no scenic spot" tourism resources, the status and functions of Hainan's tourism resources, the writer identifies 9 major "no scenic spot" tourism resources in Hainan. The resource type is shown in Table 1 as follows:

Table 1 Types of Hainan's "no scenic spot" tourism resources

\begin{tabular}{|c|c|}
\hline The resource types & Main resource forms \\
\hline Marine tourism resources & $\begin{array}{c}\text { Coastal tourism resources, Island tourism Resources, } \\
\text { Submarine tourism resources etc. }\end{array}$ \\
\hline Hot spring tourism resources & $\begin{array}{l}\text { Hot Spring Leisure Resources, Hot spring health } \\
\text { resources etc. }\end{array}$ \\
\hline $\begin{array}{l}\text { River and lake tourism } \\
\text { resources }\end{array}$ & Rivers, Waterfalls, Reservoirs, Lakes etc. \\
\hline Forest tourism resources & $\begin{array}{l}\text { Forest and its environment, Animal and plant, Landscape } \\
\text { etc. }\end{array}$ \\
\hline Shopping tourism resources & Places where tourists gather to buy tourist goods. \\
\hline $\begin{array}{l}\text { Leisure sports tourism } \\
\text { resources }\end{array}$ & $\begin{array}{l}\text { Marine sports tourism resources, Cruise tourism } \\
\text { resources, Low altitude flight tourism resources, } \\
\text { Mountain sports tourism resources, Golf tourism } \\
\text { resources, Outdoor sports tourism resources etc. }\end{array}$ \\
\hline Rural tourism resources & Characteristic countryside, Orchard, Farm, Farm stay etc. \\
\hline Town tourism Resources & $\begin{array}{l}\text { Ancient town, Cultural town, Characteristic street, } \\
\text { Characteristic Industrial Park etc. }\end{array}$ \\
\hline Folk custom tourism resources & $\begin{array}{l}\text { National culture, Festival, Residential building, Special } \\
\text { diet, National Costume, National art and craft etc. }\end{array}$ \\
\hline
\end{tabular}

Through sorting out the official websites, tourism websites and other websites of Hainan Province, reading relevant literature and travel guides, parts of the field survey, referring to the "Hainan International Tourism Island Construction and Development Program" (2010-2020) and "Hainan Provincial Master Plan Outline" (2015-2030), according to the understanding and classification of "no scenic spot" tourism of resources, the distribution of "no scenic spot" tourism resources in Hainan is shown in Table 2: 
Table 2 Distribution list of main "no scenic spot" tourism resources in Hainan province

\begin{tabular}{|c|c|c|c|c|c|c|c|}
\hline $\begin{array}{c}\text { Regional distribution } \\
\text { Quantity of resources } \\
\text { The resource types }\end{array}$ & $\begin{array}{c}\text { Northern } \\
\text { region }\end{array}$ & $\begin{array}{c}\text { Southern } \\
\text { Region }\end{array}$ & $\begin{array}{c}\text { Central } \\
\text { region }\end{array}$ & $\begin{array}{c}\text { Eastern } \\
\text { Region }\end{array}$ & $\begin{array}{c}\text { Western } \\
\text { Region }\end{array}$ & $\begin{array}{c}\text { Ocean } \\
\text { region }\end{array}$ & Total \\
\hline $\begin{array}{c}\text { Marine tourism } \\
\text { resources }\end{array}$ & 17 & 32 & 0 & 21 & 17 & 9 & 96 \\
\hline $\begin{array}{c}\text { Hot spring tourism } \\
\text { resources }\end{array}$ & 7 & 11 & 6 & 7 & 6 & 0 & 37 \\
\hline $\begin{array}{c}\text { River and lake } \\
\text { tourism resources }\end{array}$ & 11 & 25 & 26 & 17 & 44 & 0 & 123 \\
\hline $\begin{array}{c}\text { Forest tourism } \\
\text { resources }\end{array}$ & 4 & 6 & 12 & 2 & 4 & 0 & 28 \\
\hline $\begin{array}{c}\text { Shopping tourism } \\
\text { resources }\end{array}$ & 5 & 7 & 0 & 1 & 0 & 0 & 13 \\
\hline $\begin{array}{c}\text { Leisure sports tourism } \\
\text { resources }\end{array}$ & 17 & 22 & 15 & 13 & 16 & 2 & 85 \\
\hline $\begin{array}{c}\text { Rural tourism } \\
\text { resources }\end{array}$ & 50 & 39 & 30 & 18 & 24 & 0 & 161 \\
\hline $\begin{array}{c}\text { Town tourism } \\
\text { Resources }\end{array}$ & 23 & 19 & 9 & 11 & 19 & 0 & 81 \\
\hline $\begin{array}{c}\text { Folk custom tourism } \\
\text { resources }\end{array}$ & 34 & 37 & 23 & 7 & 24 & 0 & 125 \\
\hline Total & 168 & 198 & 121 & 97 & 154 & 11 & 749 \\
\hline
\end{tabular}

Note: 1. Leisure sports tourism resources by type statistics.2. Regional division is based on "Hainan International Tourism Island Construction and Development Program" (2010-2020)

\subsection{Hainan "no scenic spot" tourism resources evaluation}

According to the classification and statistics of "no scenic spot" tourism resources in Hainan, there are 9 basic types of "no scenic spot" tourism resources in Hainan Province, with 749 resource monomers, the total amount is rich, and the types are diverse. "no scenic spot" tourism resources are not as valuable as the resources that have been developed into scenic spots. However, through scientific and reasonable combination of resources and development, the value of these resources can play a collective effect. Hainan Province "no scenic spot" tourism resources are distributed in six districts, each region "no scenic spot" tourism resources have its own characteristics: the southern region has prominent resources advantages, and there are sufficient marine tourism resources, hot spring tourism resources, leisure sports tourism resources and folk customs tourism resources; rural tourism resources are concentrated in northern region; the representative resources of the central region are forest tourism resources, river and lake tourism resources; the eastern region has the advantage of developing urban and rural experience of "no scenic spot" tourism resources; there are more tourist resources in rivers and lakes in western region, and marine tourism resources in ocean region are more distinctive. The characteristics of large dispersion and small concentration are convenient to highlight the advantages of regional resources, starting from the supply side, new supply can be created to meet new demand and promote the development of tourism in Hainan.

\section{Hainan "no scenic spot" tourism resources supply path}

On the basis of classification, statistics and evaluation of "no scenic spot" tourism resources, this paper combines the changes of tourists' demand structure for Hainan tourism resources, from supply way and supply structure to puts forward the adjustment path of structural imbalance on the supply side of Hainan tourism resources, realizes the supply of traditional tourism resources to "no scenic spot" tourism resources. (Fig. 1): 


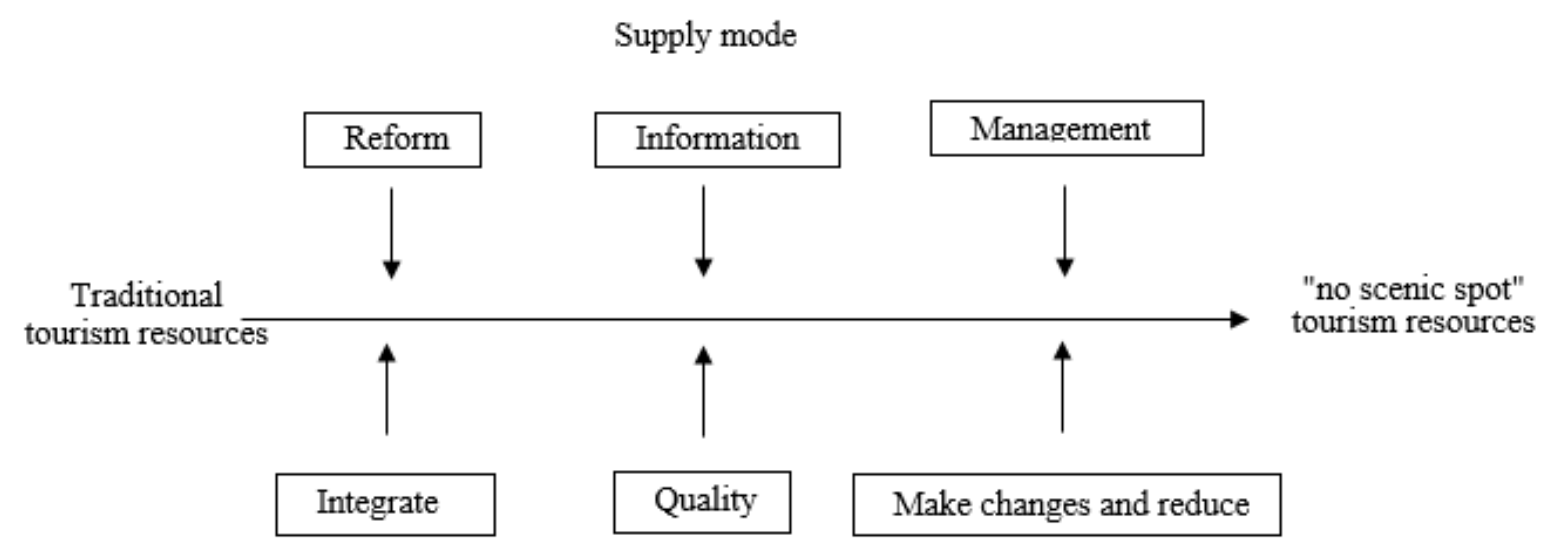

Fig. 1 "no scenic spot" tourism resources supply route

\subsection{Providing policy guarantees and implementing reform measures}

To solve the supply deviation caused by the supply vacancy and the mismatch between supply and demand, it is necessary for the government to provide a series of policies and measures to ensure the supply of "no scenic spot" tourism resources. First of all, the governments at all levels of Hainan province should take the lead in implementing the "supply-side reform", amending and adjusting the existing supply mode of tourism resources, clarifying the reasonable boundaries between the government and the market, and better coordinating with the market orientation. Secondly, to break the exclusive control of various "no scenic spot" tourism resources by different government departments, formulate tourism consumption promotion plans and tourism investment promotion plans, and increase the utilization rate of resources. Thirdly, the procedures of survey, evaluation and development of "no scenic spot" tourism resources should be optimized to facilitate the development of resources.

\subsection{Improving information transmission and reducing supply barriers}

In the supply process of "no scenic spot" tourism resources, there are mainly the following obstacles: first, tourists' awareness of the existence and value of resources is inaccurate because of incomplete and inaccurate access to information. Secondly, because of the whole regional and nonrestrictive distribution of "no scenic spot" tourism resources, which makes them less accessible and less secure, the psychological security of tourists is insufficient. Therefore, the supply of "no scenic spot" tourism resources needs to build information sharing platform, provide comprehensive and timely updated no scenic spot tourism information, through comprehensive data sharing and application, provide more comprehensive information. Creating barrier free conditions for tourists to choose "no scenic spot" tourism resources.

\subsection{Supply management and strengthening resource protection}

"No scenic spot" tourism resources take all the resources and industrial forms that can increase tourists' experience as tourism resources. On the one hand, it is a manifestation of the full use of resources, on the other hand, it may affect the original industrial layout, causing damage to resources. Therefore, in the supply process of "no scenic spot" tourism resources, we should strengthen management, standardize development, and realize the sustainability of "no scenic spot" tourism resources by defining the urban growth boundary, carrying out industrial planning, implementing ecological control line protection, and improving cultivated land protection.

\subsection{Achieving resource integration and breaking the supply screen}

Large quantity and decentralization are the basic characteristics of Hainan's "no scenic spot" tourism resources supply, which brings the tourists a difficult choice and a single experience. Therefore, it is necessary to break the shield of resources supply by combining the "point, line and plane" of "global tourism" to realize the "overall greater than partial sum" of resources value, so as 
to adjust the supply structure of "no scenic spot" tourism resources and maximize the value of regional comprehensive resources. According to the types and quantities of "no scenic spot" tourism resources in each region, the "no scenic spot" tourism products can be developed as follows: the northern region can develop rural experience tourism products, urban and rural cultural experience tourism products; the southern region can develop coastal holiday tourism products, hot spring health tourism products, leisure sports tourism products ,cultural experience tourism products; the central region can develop leisure and health tourism products and sports tourism products; coastal tourism products, rural leisure tourism products, the eastern region can develop coastal vacation tourism products, rural leisure tourism products, urban sightseeing tourism products and cultural experience tourism products. the western region can develop rural leisure tourism products and folk customs tourism products; ocean region can develop marine experience tourism products.

\subsection{Focusing on supply quality and stimulating resource demand}

The supply side reform solves the supply and demand dislocation structure, the key is to improve the supply quality. The diversification of tourists' pursuit of tourism consumption is not simply seeking novelty and difference, but focusing on the beautiful experience in the process of tourism consumption. The formation of the beautiful experience relies on high-quality tourism resources and good tourism services, and the guarantee of the supply quality can further stimulate the demand for "no scenic spot" tourism resources. To ensure the supply quality of "no scenic spot" tourism resources, first of all, we should make a good plan. The "no scenic spot" tourism resources with immature development conditions would rather be "kept in a deep boudoir" than "unveiled"; secondly, we should pay attention to the supply of supporting facilities for "no scenic spot" tourism resources to improve their accessibility and ensure that the supply can meet the demand of tourists.

\subsection{Eliminating excess supply and reducing homogeneous resources}

Driven by the interests, there is a large number of homogeneous development in the current tourism development. The homogeneous tourism supply greatly exceeds the demand, resulting in overcapacity, which makes the characteristics of tourism resources weakened and the quality of tourism supply is not high. The supply of "no scenic spot" tourism resources should solve the shortage of supply, and more importantly, the dislocation of supply and demand. "No scenic spot" tourism resources that have been developed in the same region, the same type and level should be managed and controlled, and the "classification" of homogeneous resources can be realized through resource integration, or excess supply can be eliminated, only high-quality products can be left, and other homogeneous resources can be adjusted and reduced. The undeveloped "no scenic spot" tourism resources should be carefully developed, following the principle of differentiated development and avoiding homogenous oversupply.

\section{Conclusion}

The supply path of Hainan "no scenic spots" tourism resources discussed in this paper is an effective way to optimize the supply structure of tourism resources, change the traditional tourism model, expand tourism space, improve tourism quality, and promote industrial integration and upgrading. Under the influence of supply-side reform thought, the development of Hainan's allregion tourism can be promoted by relying on diversified and abundant "no scenic spot" tourism resources, Hainan can promote the development of tourism in the whole region, cultivate new economic growth points, adjust and upgrade the industrial structure of tourism, and ultimately promote the scientific development and green rise of Hainan.

\section{References}

[1] Gan Zhimao, Ma Yaofeng. Tourism resources and development [M]. Tian Jin: Nankai University press, 2000.

[2] Wang Degen, Qian Jia. Thoughts on tourism planning system in the era of "creative 
tourism"[J].Tourism Tribune, 2014(29):13-15.

[3] Ren Guocai."4Q" resources: the third generation of tourism resources in China [N].China Travel News.September 30, 2015 (C02 Edition).

[4] Lv Junfang. The Tourism Resources Integration Development of Liaodong Bay of Bohai [J]. Henan Science, 2014(32):2631-2634.

[5] Jin Yingruo. The redundancy of tourist resources [J]. Economic Geography,2004(5):672-674. 